\title{
The Explanation of Principles and Elements of Religious Democracy with Emphasis on Constitution of Islamic Republic of Iran
}

\author{
Hossein Koshtegar ${ }^{1}$ \\ Lena Abdolkhani2* \\ Aliakbar Amini ${ }^{3}$ \\ ${ }^{1}$ Department of Political Science, Zahedan Branch, Islamic Azad University, Zahedan, Iran \\ ${ }^{* 2}$ Assistant Professor in Ahvaz Branch, Islamic Azad University, Ahvaz, Iran \\ ${ }^{3}$ Assistant Professor in Central Tehran Branch, Islamic Azad University, Tehran, Iran \\ *Corresponding author: Lena Abdolkhani, Email: koshtegar.iau@gmail.com
}

\author{
Doi:10.5901/mjss.2016.v7n2s1p79
}

\begin{abstract}
After the victory of Islamic Revolution in 1979 in Iran, a new type of government was established which emphasized religious authority along with democratic aspects which is now known as "religious democracy". Therefore, to explain the essence of this type of government one could state that religious democracy is a new interpretation of Islam in which the political aspects of Islam as a complete and comprehensive religion are considered, emphasis is on political affairs of a religious society and social and political authority of Islam is included so that it simultaneously has political and religious legitimacy in it. The primary question in the present paper revolves around explanation of principles and elements of religious democracy and better and more precise examination of its indicators in constitution of Islamic Republic of Iran.
\end{abstract}

Keywords: democracy, religious democracy, Islamic Republic of Iran, constitution.

\section{Introduction}

There are disagreements among scholars and thinkers in regard to the fact that whether religious democracy should be considered as a government which obtains its legitimacy from the public and the fact that it should be considered as a model of democracy or constitutive of a religious non-democratic government. Some believe in impossibility of establishment of democracy and formation of a democratic system in a religious state and state that the term democracy with the prefix of religious is not a clear scientific discussion but playing with words and concepts which is very dangerous in politics. Such innovations don't go well in politics (Daihimi, 2003). In his work called "An Introduction to Political Sociology in Iran", Basharieh (2007) writes:

"In this complicated structure, due to high significance of leadership and the institute of Velayat-e Faqih (guardian jurist), central role of clergymen in Guardian Council of the Constitution, Assembly of Experts of the Leadership of Iran and The Judiciary as well as the role supreme leader and Guardian Council of the Constitution in approval of the president, the national sovereignty is indirectly applied and that is why there are impediments against governing in a democratic manner".

He believes that the constitution of Islamic Republic of Iran explicitly emphasizes exclusiveness of sovereignty and canonization of God which makes Islamic Republic of Iran face "Duality of Sovereignty" (Basharieh, 2007).

In contrast, some scholars believe in internalization of principles and elements of democracy in a religious government, especially Islamic Republic of Iran. Ayatollah Javadi Amoli (2003) believes that, "The formation and persistence of divine state in the society is not mandatory and only possible through public will".

Imam Khomeini (1992) equaled democracy with being republic and introduced the latter as not as the shape of the system but as its content. Imam Khomeini regarded the three principles of collaboration, freedom and equality as the characteristics of democracy and stated that democracy is written in Islam. This means that Islam has considered democracy as one of its signed and approved principle and it is included in Islamic decrees.

In the present study, the analytic-descriptive methodology and library reviews are used to examine theoretical principles of religious democracy and explain these indicators and principles in constitution of Islamic Republic of Iran. It 
should be notes that in this regard, very few papers and books have been found.

\section{Theoretical Principles of Religious Democracy}

In the system of religious democracy, the three elements of religion, leadership and people play essential roles. This system obtains its legitimacy from religion and Sharia'. As a result, the public play a significant role in its realization. In this system, the person chosen for leadership should have the characteristics pointed out in constitution of Islamic Republic of Iran. Therefore, everyone who satisfies these qualifications can play a role in the system. Of course, it should be noted that the legitimacy of guardian jurist is not based on public approval and vote but on religious narrations and reasons. The public approval and vote do not determine the righteousness and legitimacy of guardian jurist and rule of religion but verifies the popularity of such a government. In framework of accepting Sharia', compliance with religious values and principles and acceptance of guardian jurist as one of the premises of a religious government, the public could involve and participate in distribution of political power and surveillance of different social affairs. The parties, groups and forums as well as free press as representation of civil and public activity could also appear and act in such a government (Vaezi, 2001).

Therefore, religious democracy as a model and a structure obtains its legitimacy from divine will and rules. As Bigot (2001) states, "One of the reasons for legitimacy of Iranian regime among its people is its being Islamic". If one has a true image of belief in God, position of humans and objective orientation as the three indicators of Islamic thinking in the field of beliefs, one could see that the political-governmental geometry of Islam is only realizable in framework of divine rules but the public will and votes play a significant role in Islamic government too.

In other words, religious democracy does not refer to a democratic state in its common and western sense because in western governments, the public and their representatives legislate while in an Islamic state, the legislation is divine and the public representatives plan the executive affairs based on Islamic decrees. Meanwhile, the public aspect of the issue is maintained because the set of Islamic rules collected in Quran and tradition are already accepted by Muslims. These agreement and acceptance of government premises facilitates systems' affairs and makes it a something possessed by the public. Therefore, in religious democracy, everyone from the Prophet to his substitutes and the other people in the society obey divine rule and can only rule in that framework.

\section{Position and Role of the Public in Political Structure of Islamic Republic of Iran (With Emphasis on Constitution)}

The Islamic Republic of Iran is composed of two elements of Islamic orientation and republic orientation. The republic orientation forms its structure and the Islamic orientation shapes its essence. The first article of the constitution states that,

"The government of Iran is Islamic Republic and based on long faith in government of righteousness and fairness of Quran which obtained victory through leadership of guardian jurist Imam Khomeini, the people voted for it in referendum of 30 th and 31 st March of 1979 with an approval rate of $98.2 \% "$

Regarding the ideological premises of the governmental system, second article of the constitution states that Islamic Republic is a system based on belief in one God, divine revelation, resurrection, justice of God in creation and legislation, Imamate and leadership, dignity and value of man and his freedom coupled with responsibility before God, denial of any type of cruelty and domination, justice and fairness, justice in social, political, economic and cultural affairs, etc.

The fifty sixth article of constitution states,

"The absolute rule over the world and human is owned by God and it is him who let human dominate over his social fate. Nobody can deny human from this divine right and put it at service of a specific individual or group. The nation realizes this divine right through the ways written in the next articles".

Therefore, in Islamic Republic of Iran two steps of rule are acknowledged that are parallel with each other. The first is sovereignty of God over humans and the second is domination of human on his/her social fate. These two constructs are rooted in Islamic beliefs and they may not be differentiated from each other (Shafii Far, 2006).

In regard to democratic indicators of the constitution of Islamic Republic of Iran, one could say that based on the constitution the Islamic sovereignty is based on three principles of Islam, public will of Muslims and leadership. Therefore, 
the Islamic sovereignty has whatever included in non-religious states as democracy and public cooperation in in it. In this type of sovereignty, the element of concentration of rule is used to an extent that does not lead to despotism and authoritarianism but to proper management and social guide of the public (Nabavi, 2001). The non-religious governments that only deal with the way to rule "suffer from inconsistency of their intellectual premises of regulating the public participation and proper position of head of state" (Nabavi, 2001) while the Islamic sovereignty offers a harmonic and consistent role. On the other hand, in contrast to exaggerations found in principles and legal items of new non-religious systems regarding the total role of the people based on which some of our thinkers state that in such governments the vote and choice of the public is the only criterion in codification of principles, programs and structures, the social and political of the industrial western world show something else. The truth is that "in western political world, the assignment of positions and decision-making is solely done by political parties and trends and they initially decide instead of the people and then use promotional tools to obtain the public approval" (Nabavi, 2001).

The constitution of Islamic Republic of Iran assigns the top rank of Islamic community to guardian jurist and the imam of the nation. The fifth article of the constitution states,

"In the time of absence of Imam Mahdi (BBuH), in Islamic Republic of Iran the guardian jurist and Imam of the nation would be a jurisprudent who is wise, virtuous, brave, and tactful who takes the responsibility".

In addition to divine and religious roots, this position is indirectly selected by the public. As a result the position of guardian jurist is the result of divine sovereignty and rule of the public (Zanjani, 1999). On the other hand, because the position of guardian jurist and sovereignty are regulated through other constitution principles and assigned through the other three departments, a type of power distribution occurs inside the position of guardian jurist. There are three primary centers of power that assign the position of guardian jurist and sovereignty (Shafii Far, 2007). Based on fifty seventh article of the constitution, the dominating powers in Islamic Republic of Iran are the judiciary, the executive and the legislative that executive that are independent of each other.

Therefore, following a review of the constitution of Islamic Republic of Iran the most significant role of the public in political structure of Islamic Republic of Iran is:

1- Selection of People by Assembly of Experts of the Leadership of Iran: Based on the articles of the constitution, the leader is selected by Assembly of Experts of the Leadership of Iran. This assembly is composed of Islamic experts and jurists that have qualification in recognition of the leader. Its members are eighty people that are selected once every eight years. The duties of Assembly of Experts of the Leadership of Iran are selection of leader, surveillance over his duties and deposition in the case of losing qualifying characteristics. As the leader is responsible before God and should be responsive, he also should be under constant watch by the Assembly of Experts of the Leadership of Iran. Therefore, the role of the people in selection of the leader and monitoring his tasks are indirect and based on representative democracy which is something usual in democratic states. Therefore, based on one hundred and seventh article of the constitution, the members of Assembly of Experts of the Leadership of Iran are selected by public vote. Based on this article, the selection of the supreme leader could be assigned to the public because people practically participate in determination of the leader. In this regard, this article states that, "selection of the leader is done by experts themselves chosen by the public". Therefore, the public participation and precision in selection of the leader are highly important and two satisfy both of these two criteria, an intermediate council is selected and assigned.

In addition to selection of the leader, surveillance over leader's tasks is another task of the public. In the constitution, the necessity of monitoring the tasks of the leaders and authorities are stated in the following manner:

A: In the preface to the constitution, it is written that, "It is necessary that the Muslim nation select committed and dutiful authorities and consistently and actively monitor their actions to build an Islamic society".

B: The eighth article of the constitution states, "In Islamic Republic of Iran, invitation to the virtue and prevention of the vice is a public and mutual duty that the state and the public have to fulfil in regard to each other". In this article, due to the fact that state is interpreted in its general denotation, namely the whole ruling institute, invitation to the virtue and prevention of the vice is considered as the significant tool of public surveillance over the state and supreme leader. The reverse is also the case.

2- Selection of President: Based on one hundred and fourth article of the constitution, the people directly selected the president and chief executive director of the country and this represented the domination of the public over their social fate. Based on a hundred twenty second article of the constitution, the president is responsible before nation, leader and the Islamic Consultative Assembly for his actions. The responsibility of 
president against nation is initially based on the task initially assigned to him to execute the constitution.

3- Selection of Parliament Members: Based on sixty second article of the constitution, the members of Islamic Consultative Assembly are directly selected by the people. As the constitution states, the members of Islamic Consultative Assembly should legislate laws in different judicial and executive fields. The Islamic Consultative Assembly can interpolate or question the president or any one of ministers. Based on seventy sixth article of the constitution, the Islamic Consultative Assembly can apply surveillance over all national affairs. It also selects six lawyers of Guardian Council of the Constitution after the introduction of candidates by the head of the judiciary system. All of these elements signify the public rule over national and social direction of the country. On the other hand, the public also monitor the performance of Islamic Consultative Assembly. In general, three ways have devised for public surveillance over performance of the assembly. These are surveillance through broadcasting the account of assembly negotiations, surveillance through presence in assembly and surveillance through Committee on the 90th Article of the Constitution. As a result, the public communicate with the members regarding the national conditions and tell the members their complaints as the last solution (Mehrpur, 1993).

4- Selection of Urban and Village Islamic Councils: Based on one hundredth article of the constitution, the quick progress of social, health and cultural programs through public participation and management of provincial, urban and village affairs are assured through surveillance of the councils the members of which are selected the local people and direct vote. Therefore, the selection of members of Islamic councils to fulfill their distinctive tasks as codified in the associated laws and surveillance over proper execution and plans are limited to their electoral district and in affairs defined in the law (one hundredth article of the constitution).

\section{Results}

The result is that with a general review of the constitution, one could say:

1- The people play the main role in establishment and continuation of the Islamic Republic system an instance of which is formation and victory of the revolution. The determination of type of system was done with $98.2 \%$ of those with right to vote approving Islamic Republic.

2- The approval of the constitution and its reforms done in $3^{\text {rd }}$ December 1979 and those done in 1989 were done by the public vote.

3- In the constitution, the political system of Islamic Republic Revolution is based on public vote and for their service. Therefore, the ultimate criterion is the public.

4- In Islamic Republic system, the people participate in all critical and non-critical organizations and institutes. This participation is realized either directly or indirectly.

5- Due to the reasons of invitation to the virtue and prevention of the vice as well as necessity of public intervention in their own fate, the public surveillance over the authorities is their right and duty because the performance of the systems and national authorities is directly affecting the fate of individuals. So, it is right of the people to monitor national affairs and to intervene in their fate. In contrast, one should note that this right cannot be assigned to another person and each person should be act responsibly in this regard.

6- The Islamic Republic system is in its totality a system based on religious democracy. The public monitor all of the three national departments from the judiciary over which surveillance is done by direct or indirect representative of the public (i.e. supreme leader and parliament) up to surveillance over the leadership, the executive and the legislative in regard to which the guarantee of execution of law by authorities is done through litigation, Supreme Court, Court of Administrative Justice and The General Inspection Organization of Iran (GIO). Based on the constitution of Islamic Republic of Iran, the public play a critical role in establishment and continuation of Islamic system and there is no non-democratic aspect in it.

\section{Conclusion}

The religious democracy the most vivid instance of which is Islamic Republic is a modern model of democracy in the present era and despite of its numerous similarities with common model of democracy in the west there are significant differences between the two. Among the outstanding distinctions of the two is priority of religion. Therefore, the constitution of Islamic Republic of Iran is the true image of unity and representation of state-public relations with two basic characteristics: people and Islamic orientation. These two characteristics guarantee the independence, dignity, development and perfection of the society and determine the limits of the nation and the state. Therefore, the primary 
foundations of Islamic Republic of Iran are Islam and the public as two factors affecting the victory of Islamic Republic in 1979.

In Islamic Republic of Iran, people selected Islam as the religion and way of social and individual living. They try to create a social contract to manage their society based on Islam and establish social entities based on Islamic teachings. This requirement dominates all other requirements they have. In this regard, the constitution is written based on teachings of Islam and verified through the vote of majority of the people. The leader is selected by the vote of majority of the public (through Assembly of Experts of the Leadership of Iran) and president is directly selected through direct vote of the people. In addition, the people select the members of parliament and councils. Therefore, the people play two fundamental roles in a religious democracy system. They select the political rulers in either direct or indirect manner and they participate in decision and policy making. These two issues should be based on religious rules the determination of which is done by jurist which is also known as surveillance. In other words, one of the principles attended to in the constitution is "public surveillance" which is directly done by the public and regarded as a preventive factor against deviations of authorities. Therefore, all of the people have this right and duty. The constitution of Islamic Republic of Iran originates from public opinion which is realized through selection and surveillance. It is simultaneously at service of the public. Therefore, the position and role of the people in the constitution are not merely one-way. This means that the system is based on the public approval and its objectives are defined in a way that success and happiness of the people in this world and the world after are guaranteed.

\section{References}

Basharieh, H. (2006). A transition to democracy. Tehran: Negah Moaser Press.

Bigot, J. (2001). The future of Iran: New face of Iran, In Jadi Nia, M (Edit.), Journal of World of Art.

Daihimi, K. (2003). Religious democracy: An innovation in politics. Tehran: Aftab Press.

Javadi Amoli, A. (2003). Velayat-e-Faqih: Domination of Justice and Jurisprudence. Qom: Asra Publications.

Khomeini Mosavi, R. A. (1992). Sahife Noor. Tehran: The Institute for Publication of Imam Khomeini's Work.

Mehrpur, H. (2007). Collection of theories by Guardian Council of the Constitution from July 1980 to July 1986. Tehran: Kaihan Press.

Nabavi, A. (2001). Democracy in Islamic sovereignty. Journal of Islamic Civilization and Development, 8: 36-59.

Shafii Far, M. (2006). Democracy in constitution of Islamic Republic of Iran: Limits of state power. Journal of Islamic Revolution Studies, 2:115-156.

Shafii Far, M. (2007). The position of Velayate-Faqih in constitution of Islamic Republic of Iran, Islamic Government Quarterly, 13: 62-94.

Vaezi, A. (2001). Religious state. Qom: Mersad publication.

Zanjani, A. (1999). Islamic jurisprudence. Tehran: Amir Kabir Press. 